\title{
Flight Delays, Security and Economic Reimbursements
}

\author{
PhD Candidate Ardit Çela \\ European University, Albania \\ E-mail: acela9@hotmail.com \\ PhD. Klodian Muço \\ Catholic University "Our Lady of Good Council” \\ Research Centre on Economics of Transition Countries, Albania \\ E-mail: k.muco@unizkm.al
}

Received: April 5, 2020 Accepted: April 17, 2020 Published: May 6, 2020

doi:10.5296/ber.v10i2.16985 URL: https://doi.org/10.5296/ber.v10i2.16985

\begin{abstract}
Over the past decade, the air transport system has undergone profound changes, mainly driven by the evolution of reference legislation and markets globalization process. The primary cause also goes by the name of "deregulation", which has profoundly revolutionized the tariff methodology and air transport management.

With deregulation, airlines have seen disappear of barriers and constraints that incentivized growth and development for many years (Arrigo, Giuricin, 2006; Postorino, 2009).

The globalization of markets has also proved decisive in the growth of demand for air transport, which has become an irreplaceable means of transfer that allows the connection from one part of the terrestrial globe to another in a few hours. Impressive growth in air traffic and deregulation has at the same time led to millions of frequent passengers and unpleasant complications, such as delays. In the absence of a specific discipline in this area and with the desire to give balance to a situation partially unbalanced to the detriment of consumers/travelers, the European Union decided to take action to remedy it, equipping passengers with effective protection tools against these afore mentioned situations.

The European Union has made the rules issued in 1991 on compensation and assistance to air passengers more rigid and afflictive for airlines by providing, at the same time, new provisions aimed at mitigating the inconvenience of passengers abandoned at airports due to canceled flights or of prolonged delays. The EU legislation covering these changes, which
\end{abstract}


was preceded by the Passenger Rights White Paper, is contained in EU Regulation 261/1994, which came into force in February 2005, which sets out how and operational rules on assistance and reimbursement to air traffic users (Fraschina, 2009).

The three different hypotheses of "denied boarding", cancelled flights and prolonged delays are the subject of regulation.

In this study, however, we will mainly address the rights and reimbursement of passengers in the event of delays of air flights, in fact according to the new legislation, more protection will be provided to passengers who will face the painful and common circumstances of the delays. Community bodies believed that adequate assistance and reimbursement should be provided to passengers who were forced to long waits at airports due to a flight delay.

Keyword: Passenger Rights, Security, Overbooking, Consumer Protection, Refunds

\section{Plane Delay and Consumer Protection}

We live in the age of globalization and low cost, and for all ofus flying has become a now obvious and habitual way of traveling and transferring goods from one point to another in the world. Air transport is now one of the main drivers of the global economic boom. At the same time,"part" of air travel, the term "delay" is, in all respects, one of the forms of failure of the air carriers. It is undeniable that the behavior of the carrier, which has delayed or even denied boarding to a passenger with a confirmed booking, legally constitutes a non-compliance with the transport contract.

The problem that exists is to clarify what should be understood by delay,a source of indemnification obligation. As is well known, the jurisprudence of the justice of the peace has recently tried to answer this question, which on various occasions has affirmed the liability of air carriers (Romana, 2005).

For all transport companies in general, timetables are an essential element of transport, whatever it may be (rail, road, air, sea): in these terms in air transport, even more so, the connection between the indications timing and speed of transfers is one of the factors that most determine the choice of the aircraft. According to an ENAC definition, "delayed flight" it is intended as a flight departing with more than 15 minutes delay compared to that published by the relevant airline.

It should be pointed out that delay, beyond the code forecast, assumes a new function, that of measuring the quality level of the service provided by the air carrier. According to Romana (2005) the consequence of the allocation of this new function is the full applicability, to the cases in question, of the protection referred to in Law 281 of 1998, precisely with reference to the letter g) of Article 1, which is beneficial to repeat and enshrines the fundamental right of the consumer/user to the provision of public services according to standards of quality and efficiency.

According to the EC Regulation of the European Parliament and of the Council of 11 February 2004, n. 261 and international legislation on delay in air transport, applies to passengers departing from an airport located in a Member State; to passengers departing from 
an airport located in a third country with a destination located in a Member State airport. All if passengers have a confirmed booking and show up at check-in according to the modalities and time schedules (Fraschina, 2009). This regulation, in essence, aims to give greater protection to passengers by increasing the amount of compensation on account of the distance to travel.

The concept of delay is not defined in the Regulation, although the by the same text can be deduced that there is delay whenever an aircraft takes off beyond thescheduled time of departure.

According to the Passenger's Bill of Rights published by ENAC (ENAC, 2009), the air carrier is required to provide assistance under the Regulation in case the flight is delayed from the scheduled time of:

-two or more hours for routes of $1500 \mathrm{~km}$ or less;

-three or more hours for intra-EU routes greater than $1500 \mathrm{~km}$ and for all other routes between 1500 and $3500 \mathrm{~km}$;

-four or more hours for all other routes that are not covered by the first two cases.

If the flight is postponed to the next day, passengers will be entitled to an overnight at the hotel. Only if the delay is more than 5 hours will passengers be entitled to request a refund of the airfare, if they cannot postpone the departure to another date or the delay is excessive for their travel schedule. In any other case, if the passenger can prove the damage suffered due to the delay, he will be entitled to ask the carrier for the compensation provided for by the Montreal Convention.

The compensation, referred to in the articles of Regulation 261, due to the passengers concerned amounts to:

- $€ 250.00$ for routes below or equal to $1500 \mathrm{~km}$;

-€400.00 for intra-EU routes greater than $1500 \mathrm{~km}$ and for all other routes

Included between 1500 and $3500 \mathrm{~km}$;

- €600.00 for routes not included in the first two cases. If passengers are offered an alternative flight whose timetable does not exceed, respectively, 2, 3 or 4 hours compared to the originally scheduled time for the booked flight, the carrier can reduce the compensation by $50 \%$.

Compensation must be from the carrier confirmed in writing to the passenger and is paid in cash, i.e. by bank transfer, by check or, if there is agreement, with travel vouchers or other services, all within 7 days of the event. In all cases referred to by Regulation 261, the passenger is entitled, free of charge to:

-meals and drinks in a fair relation with the waiting time;

-accommodation in the hotel, if this is made necessary by the extension of the wait; 
-transport between the airport and the place of accommodation for the overnight stay. The passenger is also entitled to make 2 telephone calls or to send e-mails free of charge. In applying the above, the carrier must have to pay special attention and priority to the needs of people with reduced mobility and their caretakers, as well as to the needs of unaccompanied children.

In the case of an alternative flight, a change in class may be imposed for the need of available seats.

In this case: upper class: the carrier will not be able to request any additional payment from the passenger; Lower class: the carrier will have to reimburse the passenger, within 7 days, $30 \%, 50 \%$ or $75 \%$ of the cost of the ticket, depending on the distances indicated in the previous cases.

The obligations to passengers, as set out in Regulation 261, may not be restricted or waived, not even as a result of derogatory or restrictive clauses included in the transport contract.

With the Legislative Decree 27/01/2006 nr. 69, the Italian legislator introduced the sanctions applicable to the carrier in the event of violation of the provisions of the EU Regulation no. 261/04, also identifying in ENAC the national body responsible for applying it and in imposing the consequent sanctions.

If the air carrier does not comply with the obligations and procedures of Regulation 261, it will be subject to the following sanctions:

- denied boarding: administrative penalty from $€ 10,000.00$ to $€ 50,000.00$

- flight cancellation: administrative penalty from $€ 10,000.00$ to $€ 50,000.00$

- flight delay: administrative penalty from $€ 2,500.00$ to $€ 10,000.00$

- class change: administrative penalty from $€ 1,000.00$ to $€ 5,000.00$

- people with reduced mobility - unaccompanied children: administrative penalty from $€ 10,000.00$ to $€ 50,000.00$

- obligation to inform: administrative penalty from $€ 2,500.00$ to $€ 10,000.00$

The penalties imposed in this way may be opposed by the carrier in accordance with the normal procedure provided by law $689 / 81$ in relation to the opposition to administrative sanctions.

\section{Overbooking and Protection of the Traveler in Air Transport}

The term overbooking is, for all intents and purposes, one of the forms of failure of the air carrier. It is undeniable that the behavior of the carrier, which has denied boarding to a passenger with a confirmed booking, legally constitutes a non-compliance with the transport contract. Overbooking or rather as called overselling (Busts, 1994) today is the practice by which airlines intentionally accept a fewbookings for a given flight in excess of the actual seats available on the aircraft. For airlines, overbooking is often a compulsory choice, which 
is based on precise statistics arising from the actual booking/boarding ratio and is aimed both at ensuring passengers meet the requirements and avoiding the economic harm that could result from carrying out a flight with far fewer passengers than they could have boarded.

Of course, this practice has also led to considerable difficulties for those users who are denied boarding, but also damages for the airlines since, at a certain point, the passengers started filing their lawsuits for damage claims, the duration and costs of which often exceeded the same amount of damage suffered (Pruneddu, 2011).

Today, however, airlines leave enough time to purchase them after a certain time, however, they have the right to cancel a passenger's booking in the event that they do not proceed to the purchase of the ticket within a specified period of time since they booked the flight. This system has, over time, been extremely effective in the "fight" against false bookings and, the companies that adopted it, still tend to keep it in place today (Pruneddu, 2014).

Among the first bodies to deal with the phenomenon in a "scientific" way is the CAB Civil Aeronautics Board, which, in 1982, aimed to find ways to reduce the number of passengers involved in the practice, but without prohibiting its use or interfering with the booking operations of the airlines.

The $\mathrm{CAB}$ set up a system of compensation schemes for passengers (which replaced compensation from the same introduced twenty years earlier), with rules for determining boarding priorities.

The introduction, both at international and EU level of the so-called compensation schemes for denied boarding, was the element that contributed the most to the regulation and solution of the overbooking problem (Pruneddu, 2011).

Community regulation and passenger protection from overbooking.The concept of protecting passengers from overbooking in air transport has officially made its "entry" into the Community institutions since the 1980s, when they became aware of the limits of compensation schemes. In 1989, a first draft, unapproved regulation was reached, followed shortly thereafter by the newCommunity legislation on the subject.

The EEC Regulations February 4, 1991 no. 295. With the introduction of Regulation 295 was created a common European regulation on compensation for denied boarding, aimed at guaranteeing certain protection for passengers and the setting of minimum and common standards for all users in the case, in fact, denied boarding due to overbooking. Based on art. 1 the Regulation applied to cases in which boarding on a scheduled flight overbooked and passengers with a confirmed reservation was denied, departing from an airport located in the territory of a Community state, regardless of the Country of nationality of the air carrier, the nationality of the passenger and the place of destination.

Regulation 295 gave the individual citizens the right to protect the subject in front of ordinary judicial authority. The Rules, from the point of view of passenger protection, provided in his favour the right to choose between:

-the refund of the ticket price for the part of the tripnon-made; 
-an alternative flight departing as soon as possible;

-an alternative flight at a later date.

In addition to the above choice, the Regulation required the air carrier to pay the passenger a minimum compensation immediately, the amount of which was proportional to the length of the lost flight. There were also some recommendations to be followed by the airlines, such as the priority in the boarding of disabled people or, in any case, with physical difficulties, unaccompanied children.

The procedure for finding volunteers who would give up on departing for benefits and compensation was then recommended, and in some cases made mandatory.

The rules established by the individual companies, in accordance with Regulation 295, were to be made available to the public in agencies and at the acceptance desks. In the years since Regulation 295/91 was enacted at EU level, it was considered appropriate to extend the scope by extending it to flights from outside Europe and to EU airports, as well as non-scheduled flights. It was also considered useful to act with preventive measures, in order to dissuade carriers from the practice of overbooking or, at least, from abusing it. This discussion led, ten years later, to the adoption of the new EC Regulation of 11 February 2004 nr. 261 mentioned in the previous paragraph which establishes common rules on compensation and assistance to passengers in case of denied boarding, flight cancellation or prolonged delay, with the simultaneous repeal of the previous Regulation 295/91. The new Regulation, in essence, aims to give greater protection to passengers not only for overbooking but also for other causes that may deny boarding.

\section{Airline Responsibility for Luggage Loss}

The carrier's liability for loss, destruction or damage to baggage, already provided for in the 1929 Warsaw Convention, is now regulated by Articles 17 and 20 of the 1999 Montreal Convention, which essentially maintains the structure of the 1929 Warsaw Convention, while deeply reviewing the regime of responsibility and documentation in the air transport of persons (compared to which it also significantly changes the criteria for judicial liaison) (Comenale, 2003).

Among the various novelties, one of the most important and interesting is the renunciation of the general hypothesis of exoneration of the liability of the carrier, now explicitly and specifically identifying the content of the release evidence against the carrier.

The new Montreal regime introduces the distinction between checked baggage that is in the custody of the carrier and carry-on baggage, providing for a different liability regime for the carrier: objective in the first case (actually almost objective) and with a burden on the passenger for the second (in the sense that the burden of proving the fault of the carrier or its employees or supervisors will fall on him).

Essentially, for the baggage delivered, the Montreal Convention stipulates that the carrier should be held accountable for the loss and damages for the mere fact that a malicious event has occurred, unless the carrier proves that the malicious event is derived from nature or a 
proper vice of baggage. ${ }^{1}$

In the case of unsigned baggage, however, the Montreal scheme, not deviate from the previous system, requires the carrier to respond to damages attributable to its fault or that of its employees and officers, provided that the passenger is able to provide such sense of evidence (Attili, 2009).

From a legal point of view, it seems interesting to analyze the case of the "almost objective" liability introduced by the Montreal Convention, for which it is sufficient, for the purposes of its application, that the baggage delivered, at the time it happens is in the custody of the carrier.

With the new regime, the element that characterizes the carrier's liability for damage or loss of baggage is the safekeeping of it.

In order to "mitigate" the objective liability regime introduced, the Montreal Convention provided, in art. 20, a general case of exemption in favor of the carrier in all cases where the damage was, in all or part, caused by an unlawful act or an omission by the passenger.

In all cases of loss, damage or delayed delivery of checked baggage, the passenger will be entitled to damages from European airlines and countries that adhere to the Montreal Convention, unless the passenger has supplementary insurance.

Every year, unfortunately, the number of lost or poorly handled baggage (by sending to a destination other than that of the passenger) increases, with a cost to airlines that is around 2.5 billion dollars. Not to mention the damage and inconvenience suffered by passengers (Capodiferro, 2009).

To cope with this phenomenon, several airports (Amsterdam, Malpensa, Las Vegas, Hong Kong, Shanghai, Beijing, Seoul, Singapore, Sydney, Manila, Bangkok) have decided to adopt an innovative system that involves the use of robots and RFID technology for the handling and tracking of handled luggage. The goal of this is to achieve a complete tracking of the baggage managed by applying a tag (label) from the moment of acceptance to check-in and up to boarding the plane. This method has already improved and will improve the problem of lost luggage in the future.

\section{Acknowledgement}

This article was written during the period in which the author served as member of the supervisory board of the National Air Traffic Agency, ANTA.

\section{References}

Attili, E. M. A. (2009). La Ripartizione di responsabilità nell'esercizio dell'handling aeroportuale relativamente al trasporto aereo di persone.

Attili, E. M. A. (2009). The Distribution of Responsibility in the exercise of airport handling

${ }^{1}$ On 28 May 1999, the unification of certain rules relating to international air transport, signed in Montreal on 28 May 1999. (text as amended as a result of the revision of the limits provided by the Art. 24, effective January 1, 2010, with the Correction to art. 35 as reported in the Official Journal of the European Union L 369 of 24 December 2014. 
in relation to the air transport of persons. p. 114.

Busts, S. (1994). Responsibility of the air carrier for overbooking, in the limit of compensation in the order of transport, systematic profiles and current issues, acts of the conference in Modena. Milan, 171.

Capodiferro, L. (2009). Overbooking and protection of the air transport traveler. Libero istituto universitario Carlo Cattaneo.

Capodiferro, L. (2009). Overbooking and protection of the air transport traveler. Free University Carlo Cattaneo. p.19.

Capodiferro, L. (2009). Overbooking e tutela del viaggiatore nel trasporto aereo. Libero istituto universitario Carlo Cattaneo.

Comenale, P. M. M. (2003). La responsabilità del vettore aereo dalla Convenzione di Varsavia del 1929 alla Convenzione di Montreal del 1999. Dirittoo e storia, 2.

Comenale, P. M. M. (2003). Responsibility for the air carrier from the 1929 Warsaw Convention to the 1999 Montreal Convention. p. 7.

ENAC. (2009).

https://www.enac.gov.it/repository/ContentManagement/node/N756388735/Carta_dei_diritti_ dei_passeggeri_6ed_nov09_web.pdf

Fraschina, M. (2009). La disciplina del ritardo nel trasporto aereo: il diritto alla compensazione pecuniaria in caso di ritardo del volo di almeno tre ore. sentenza della corte di giustizia ce, sez. iv, 19 novembre 2009, n. 402, Rivista giuridica della circolazione e dei trasporti - Automobile Club d'Italia.

Fraschina, M. (2009). The discipline of delay in air transport: the right to financial compensation in the event of a flight delay of at least three hours. Court of Justice judgment, $6,2$.

Postorino, M. N. (2009). Introduzione alla pianificazione del sistema di trasporto aereo. FrancoAngeli.

Pruneddu, G. (2011). Overbooking and health condition of passengers. R. TRANQUILLI-LEALI-EG ROSAFIO (edited by), Air transport between EU and uniform regulations. Milan, 619. 547.

Pruneddu, G. (2011). Sovraprenotazione e condizione di salute dei passeggeri. R. Tranquilli-Leali-Eg rosafio (a cura di), Il trasporto aereo tra normativa comunitaria ed uniforme, Milano.

Pruneddu, G. (2014). Legal issues of low-cost airlines. p. 142.

Pruneddu, G. (2014). Problematiche giuridiche delle compagnie aeree low cost. Università degli studi di Sassari.

Romana, N. (2005). Ritardo del vettore e tutela del consumatore. A. ANTONINI-B. FRANCHI (a cura di), Il diritto aeronautico a cent'anni dalprimo volo, Milano. 


\section{Macrothink}

Business and Economic Research

ISSN 2162-4860

2020, Vol. 10, No. 2

Warriors, G. (1989). Overbooking, Overselling and Denial of Bording, in A.A.S.L. p. 191.

\section{Copyright Disclaimer}

Copyright for this article is retained by the author(s), with first publication rights granted to the journal.

This is an open-access article distributed under the terms and conditions of the Creative Commons Attribution license (http://creativecommons.org/licenses/by/4.0/). 